\title{
農薬の植物による取り込みモデル
}

\author{
藤 澤 卓 生 \\ 住友化学工業（株） 生物環境科学研究所 \\ 干665-8555 兵庫県宝塚市高司 4-2-1
}

(平成 14 年 3 月 1 日受付, 平成 14 年 4 月 24 日受理)

\section{Model of the Uptake of Pesticides by Plant}

\author{
Takuo FUJISAWA* \\ Sumitomo Chemical Co., Ltd., Environmental Health Science Laboratory, 2-1, Takatsukasa 4-Chome, \\ Takarazuka, Hyogo 665-8555, Japan
}

\begin{abstract}
The government agencies for pesticide registration in USA and EU are now adopting a tiered approach to evaluate pesticides. In this system, they are beginning to allocate important roles to computer simulation models as a screening tool, in order to handle the vast number of pesticides waiting to be registered or re-registered. To date, a number of plant uptake models for pesticides have been published, although no plant uptake model is in practical use in risk assessment for regulatory purpose. Recently, EU authorities reported the usage of the PlantX model developed by Trapp et al. in the European Union System for Evaluation of Substances (EUSES). With this as a foothold, it is well predicted that the increasing demand for more accurate plant uptake models will evolve in the future. The basic concept adopted in these models is the partition-based theory which expresses translocation and distribution of the pesticides via changes in the equilibrium of concentration between different phases or adjacent compartments. This review will summarize the foundation of the partition theory including fugacity as well as applications to these models.
\end{abstract}

\section{1. は じめに}

農作物の安定供給の為に散布される農薬の環境中での挙 動ならびにその残留量を明らかにすることは様々な毒性評 価とともに農薬の安全性評価を行う上で非常に重要であ る，農作物や土壤，各種水系における農薬の残留量は実場 面（固場，河川水など）から採取されたサンプルの残留分 析により測定, 定量されているが, これらモニタリングに は多大な時間, 費用, 労力を必要とするとともに, 得られ た結果は散布形式（剂型, 散布量・方式, 回数など）や自 然要因（各種気象要因, 地形, 地質など）など様々な条件 に依存しており，潜在的にバラツキとなる要因を多大に含 んでいる事から，その解釈には慎重を要する。

このような実測值データでの問題点に対応するため, 欧 米では農薬登録の際の環境影響評価についてシミュレー

\footnotetext{
* To whom correspondence should be addressed.
}

ションモデルが活用されており，特に湖沼や河川を含む表 層水・地下水污染性評価が各種の既存剂ならびに新規剂に ついて実施されている。本格的なシミュレーションモデル の開発は主として米国 EPA (Environmental Protection Agency）にて始められた. Carsel ら（1984）により開発さ れた体系的なシミュレーションモデルである PRZM $^{1)}($ Pesticide Root Zone Model）は，土㙵や植物に散布した農薬の 根域および土壤不飽和層（土㖶間吵が水により飽和されて いない土鎄層）での挙動を予測するもので，その後数回の 改訂がなされている。現在は, 水系に流入した農薬の分解・ 挙動を予測する EXAMS ${ }^{2)}$ (Exposure Analysis Model System) (1990) とともにPRZM/EXAMS モデルとして水生生 物への影響評価, 飲料水からの暴露評価について現実の農 薬登録状況下で使用されている.

農薬の環境挙動評価におけるシミュレーションモデルは (1)実耕作場面を想定した様々な自然状況下での挙動を予測 できる点，(2複数の農薬を同一条件下において評価できる 
点, (3適切なモニタリング試験の設計に活用できる点, (4) 固場試験に要する時間・費用・労力を軽減できる点等の長 所が考えられる. 一方, その反面入力データの信頼性はも とより，農薬及び環境挙動に関する知識とともに使用者の モデル原理の限界に対する充分な理解が必要とされ, 的確 な使用により始めてシミュレーションモデルの有用性が発 揮されることとなる。

PRZM, EXAMS に代表されるように, 移行, 分配, 分解 過程に基づいた農薬の自然環境中での挙動を解析するシ ミュレーションモデルの例は多数報告され活用されてい る、環境を構成する個々の要素（大気, 土壌系, 水系, 生 物系）に焦点を当てたシミュレーションモデルも研究され ているが，生物系，特に植物に関して最も研究が進んでい るのは農薬の植物への取り込みモデルである。土堙ならび に植物に散布された農薬の植物への取り込みモデルについ ては partition-theory を基本概念としてこれまで数多くの シミュレーションモデル ${ }^{3-11)}$ が開発されてきたが, 実測值 と予測值の乘離やパラメータ取得の難しさ等の理由からご く最近まで登録における判断基準值を得るための手法とは なり得なかった。そのような状況下，1996 年に欧州共同体 (EU) で化学物質の環境中での挙動を総合的に予想するシ ミュレーションモデル EUSES ${ }^{12-14)}$ (European Union System for Evaluation of Substances) が開発され，その中で Trapp \& Matthies らの PlantX ${ }^{5)}(1995)$ が植物への取り込み モデルとして初めて採用された。このように実際の登録場 面にて植物への取り込みモデルが使用されるようになった ことをきっかけとして, 今後ますます化学物質ひいては農 薬の登録に際して植物への取り込みモデルの重要性は高 まっていくものと考えられる.

本レビューでは, 農薬および一般化学物質の植物への取 り込み・分布に関する基本概念ならびにモデルへの応用に ついて記述する。

\section{2. 植物への取り込みモデル概要}

既存の植物への取り込みモデルにおいて農薬の植物への 取り込み経路は, 根からの吸収, ならびに植物表面（主と して葉面）からの吸収に大別される。根からの取り込みを 考えた場合, 農薬は葉面の気孔より植物体内の水が水蒸気 として放出される際生じる蒸散流という水の流れにのって 根から水分とともに取り込まれる. 空気中に存在する農薬, もしくは散布により直接植物に付着した農薬については, 例えば葉面を考えた場合, まず表面に存在するクチクラ層 へ農薬が吸着分配され, 拡散浸透により更に植物体内に取 り込まれる. 植物への取り込みモデルを構築する上ではこ れらの取り込みに関わる現象を如何にして数理式に表すか が肝要であり，その基本概念として熱力学的平衡に基づく fugacity の概念を含む分配モデル (partition-theory) が多用
されている.

\section{2-1. PlantX モデルの概要}

\section{2-1-1. Briggs らのモデル（基本概念）}

植物での分配モデルの基本となる考え方が, Briggs $ら^{15,16)}$ により示されている. Briggs らはTSCF (Transpiration Stream Concentration Factor) という係数を用いて, 蒸散流を通じた非解離性農薬の根からの受動的な取り込み 効率を示している（図1).

$\mathrm{TSCF}=($ 蒸散流中の農薬濃度 $)$

/(根を取り囲む水溶液中の農薬濃度)

蒸散流中の農薬濃度については, 導管中より直接蒸散流を サンプリングし, その農薬濃度を求めるのは困難であるた め, 通常植物中に取り込まれた農薬 $(\mathrm{g})$ を全蒸散流量 $\left(\mathrm{m}^{3}\right)$ で除した值を用いる。

Briggs らは aldicarb, aldoxycarboxamyl, phenylurea 系化 合物等の $\log \mathrm{K}_{\mathrm{ow}}$ (水/1-オクタノール分配係数) の異なる非 解離性物質を用いて TSCF と $\log \mathrm{K}_{\mathrm{OW}}$ の関係式を求めた。 オオムギにて測定した TSCF の值を縦軸, $\log \mathrm{K}_{\mathrm{ow}}$ を横軸に とり，その分布曲線をグラフ上に描いたところ，ガウス分 布に従い $\log \mathrm{K}_{\mathrm{ow}}$ が 1.8 付近でTSCF は最大值となった(図

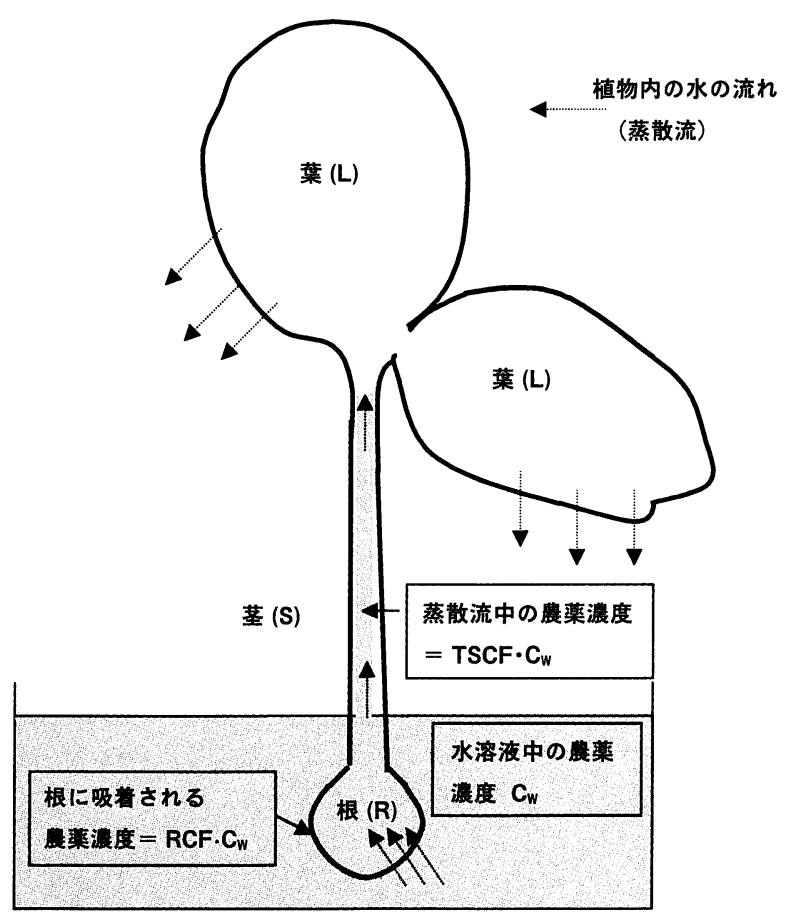

図 1 Briggs らの取り込み概念困

植物の根を水溶液に浸すと, 葉面の気孔より植物体内の水 が水蒸気として放出されるとともに根から水溶液が取り込 まれ導管中に蒸散流という水の流れを生じる。農薬の根か らの取り込みを考えた場合, 蒸散流にのって農薬は植物茎 葉部へ取り込まれる. 植物の根を取り囲む水溶液中の農薬 濃度を $\mathrm{C}_{\mathrm{W}}$ とした場合, 蒸散流中に溶解する農薬濃度は $\mathrm{TSCF} \cdot \mathrm{C}_{\mathrm{w}}$, 根に吸着される農薬濃度は $\mathrm{RCF} \cdot \mathrm{C}_{\mathrm{w}}$ と表す ことができる. 
2). オオムギでの実測值をもとに最小二乗法により近似式 を求めたところ,

$$
\mathrm{TSCF}=0.784 \exp -\left[\left(\log \mathrm{K}_{\mathrm{ow}}-1.78\right)^{2} / 2.44\right]
$$

が得られた。

一方， $\mathrm{Hsu}^{17)}$ らは oxabicycloalkane 化合物を用いてオオ ムギでの試験とは異なる圧力チャンバー法によって同様の 関係式をダイズについて以下のように導き出している.

$\mathrm{TSCF}=0.78 \exp -\left[\left(\log \mathrm{K}_{\mathrm{ow}}-3.07\right)^{2} / 2.78\right]$

このように TSCF が $\log \mathrm{K}_{\text {ow }} 2-3$ 付近で最大值を持つが ウス分布で表記される理由としては，高極性化合物は細胞 壁を主経路として通過するアポプラスト（導管等の死滅細 胞) 経由で根に流入するが, 内皮部分に存在するカスパリー 線（内皮細胞壁の木化したところ）に遮られ，少量のみ細 胞質・原形質連絡を通過するシンプラスト（穊管等の生細 胞）経由で取り込まれる。それに対して，低極性化合物は シンプラスト経由で内皮を通過し蒸散流まで到達するが細

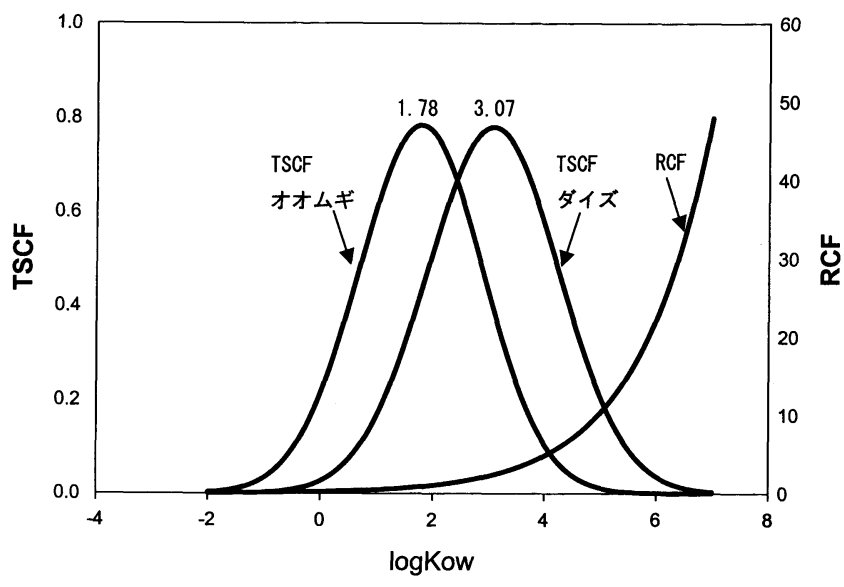

図 $2 \mathrm{TSCF}$ と $\log \mathrm{K}_{\mathrm{ow}}, \mathrm{RCF}$ と $\log \mathrm{K}_{\mathrm{ow}}$ の関係

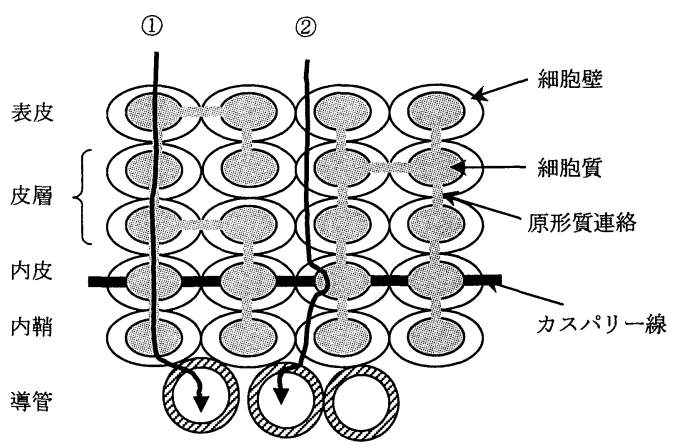

図 3 根における化合物の二つの移動経路

化合物は内皮までは細胞壁中を通って到達することができ るが内皮の細胞壁内にはカスパリ一線があるのでここから 先は細胞壁を通って内側に入っていけない. (1)細胞質, 原形 質連絡を通って移動する一低極性化合物（シンプラスト経 由). (2)通常細胞壁中を通って移動するが内皮より内側に入 る際に一度細胞膜を通過しなければならない一高極性化合 物（アポプラスト主体経由）。
胞壁から蒸散流への再分配過程において取り込み量が著し く低下する（図 3)。このような 2 つの相反する取り込み経 路において, $\log \mathrm{K}_{\mathrm{ow}}$ 2-3 付近の化合物が極性的なバランス を考慮した場合，最も植物へ取り込まれやすいと考えられ る.

また，Briggs らは TSCF と同様な考え方で外溶液から根 への aldicarb, aldoxycarb, oxamyl, phenylurea 系化合物等 の非解離性物質の受動的な吸着割合については RCF (Root Concentration Factor) という值を用いて表してい る.

$$
\begin{aligned}
\mathrm{RCF}= & (\text { 根部での農薬濃度 }) \\
& /(\text { 根を取り囲む水溶液中の農薬濃度 })
\end{aligned}
$$

RCFについても，その值は $\log \mathrm{K}_{\text {ow }}$ に大きく影響を受け以 下のような経験式が成り立つ。

$$
\log \mathrm{RCF}=0.77 \log \mathrm{K}_{\mathrm{ow}}-1.52
$$

上記式からも判断できるように TSCF とは異なり， RCF 值は $\log \mathrm{K}_{\mathrm{ow}}$ が大きくなるにつれて指数級数的に増加する 傾向が認められ（図 2)，単純な液・液間分配モデルと同じ 挙動を示す. 非解離性物質については根への吸着は根の水 分含量, 化合物の $\log \mathrm{K}_{\mathrm{ow}}$ により支配されており，化合物 種・植物種には依存されず，普遍的に適用できる。

Trapp ${ }^{18)}$ らは phenoxyacetic acid 系化合物 (弱酸性), phenethylamine 系化合物（弱塩基性）等の解離性物質の $\mathrm{RCF}$ と TSCF について $\mathrm{p} K \mathrm{a}$, 化合物電荷, 膜電荷等を考慮 しモデル式の作成を試みているが予測値と実測值との乘離 はいまだ大きく, 特にイオン性化合物の膜透過性の検討を 中心に今後大いに課題を残している.

\section{2-1-2. PlantX モデル5)}

Briggs らの TSCF の概念を取り入れて発展させたモデ ルが PlantXである.このモデルは Trappにより開発され， 現在のところ EUにおいて EUSES という化合物の環境中 での挙動を総合的に予想するシミュレーションモデルの中 で植物への取り込みモデルとして使用されている. PlantX では植物の茎葉部への取り込み量を農薬の根を取り囲む水 溶液中の濃度ならびに，農薬の空気中の濃度を基本值とし て, TSCF や異なる 2 相間の分配指標を使用し求めている. 入力デー夕は, 根を取り囲む水溶液中の農薬濃度・時間あ たりに植物中に取り込まれる蒸散流量・水/1-オクタノール 分配係数 $\left(=\mathrm{K}_{\mathrm{ow}}\right) \cdot$ ヘンリ一定数 $\left(=\mathrm{K}_{\mathrm{AW}}\right) \cdot$ 分子量・脂肪 含有量等である.

根を通じた農薬の土㙵中から植物への取り込み量は Briggs らの定義する導管中の蒸散流中の農薬濃度 $\mathrm{C}_{\mathrm{w}}$ ・ $\mathrm{TSCF}$ が基本となり， $\mathrm{C}_{\mathrm{W}} \cdot \mathrm{TSCF} \cdot \mathrm{Q}_{\mathrm{w}}$ で表される。ここで $\mathrm{C}_{\mathrm{W}}$ は根を取り囲む水溶液中の農薬濃度 $\left(\mathrm{g} / \mathrm{m}^{3}\right), \mathrm{Q}_{\mathrm{w}}$ は時間 あたりに植物中に取り込まれる蒸散流の量 $\left(\mathrm{m}^{3} / \mathrm{sec}\right)$ であ る.TSCF の実測值がない場合, 先ほど記載したオオムギと ダイズで得られた TSCF と $\log \mathrm{K}_{\mathrm{ow}}$ との関係式を使用し, 
取り込み量を計算することとなる。

化合物の空気中から葉面への流入ならびに葉面から空気 中への流出の収支 $\mathrm{N}_{\mathrm{A}}(\mathrm{g} / \mathrm{sec})$ は次式で示される.

$$
\mathrm{N}_{\mathrm{A}}=\mathrm{A} \cdot \mathrm{J} \cdot \mathrm{C}_{\mathrm{A}}(\text { 流入 })-\mathrm{A} \cdot \mathrm{J} \cdot \mathrm{C}_{\mathrm{L}} / \mathrm{K}_{\mathrm{LA}}(\text { 流出 })
$$

$\mathrm{A}$ は葉面の表面積 $\left(\mathrm{m}^{2}\right), \mathrm{J}$ は農薬の葉内面への取り込まれ やす巳 (コンダクタンス, $\mathrm{m} / \mathrm{sec}$ ), $\mathrm{C}_{\mathrm{A}}$ は農薬の空気中の濃 度 $\left(\mathrm{g} / \mathrm{m}^{3}\right), \mathrm{C}_{\mathrm{L}}$ は農薬の葉中の濃度 $\left(\mathrm{g} / \mathrm{m}^{3}\right), \mathrm{K}_{\mathrm{LA}}$ は空気 $(\mathrm{A})$ と葉（L)に㧍ける分配係数である。

分配係数 $\mathrm{K}_{\mathrm{LA}}$ については実験により得ることが困難で あるため, 水と葉面の間の分配係数 $\mathrm{K}_{\mathrm{Lw}}$ と水と空気の間の 分配係数（ヘンリー定数） $\mathrm{K}_{\mathrm{AW}}$ を用いて次式により間接的 に求める.

$$
\mathrm{K}_{\mathrm{LA}}=\mathrm{K}_{\mathrm{LW}} / \mathrm{K}_{\mathrm{AW}}
$$

ここで, 熱力学的平衡状態にある葉 $(\mathrm{L})$ と水 $(\mathrm{W})$ の間 の分配係数 $\mathrm{K}_{\mathrm{LW}}$ については以下の計算式より得る.

$$
\mathrm{K}_{\mathrm{LW}}=\left(\mathrm{W}_{\mathrm{L}}+\mathrm{L}_{\mathrm{L}} \cdot \mathrm{K}_{\mathrm{ow}}{ }^{\mathrm{b}}\right) \rho_{\mathrm{L}} / \rho_{\mathrm{w}}
$$

$\mathrm{W}_{\mathrm{L}}$ と $\mathrm{L}_{\mathrm{L}}$ はそれぞれ葉中の含水率と脂肪含有率 $(\mathrm{g} / \mathrm{g})$, $\rho_{\mathrm{L}}$ と $\rho_{\mathrm{W}}$ は葉ならびに水の比重 $(\mathrm{g} / \mathrm{l}), \mathrm{b}$ は葉中の脂肪と $1-$ オクタノールの相違を補正するための係数である. 補正係 数である b は植物部位により異なるが濃アルカリ処理 (マーセル化) した茎では $0.95^{19)}$ ，根では $0.77^{15)}$, 破砕した 根と茎では $0.75^{16)}$ という数字が得られている.

この基本関係式より得られた $\mathrm{K}_{\mathrm{LW}}$ を用いて最終的に式

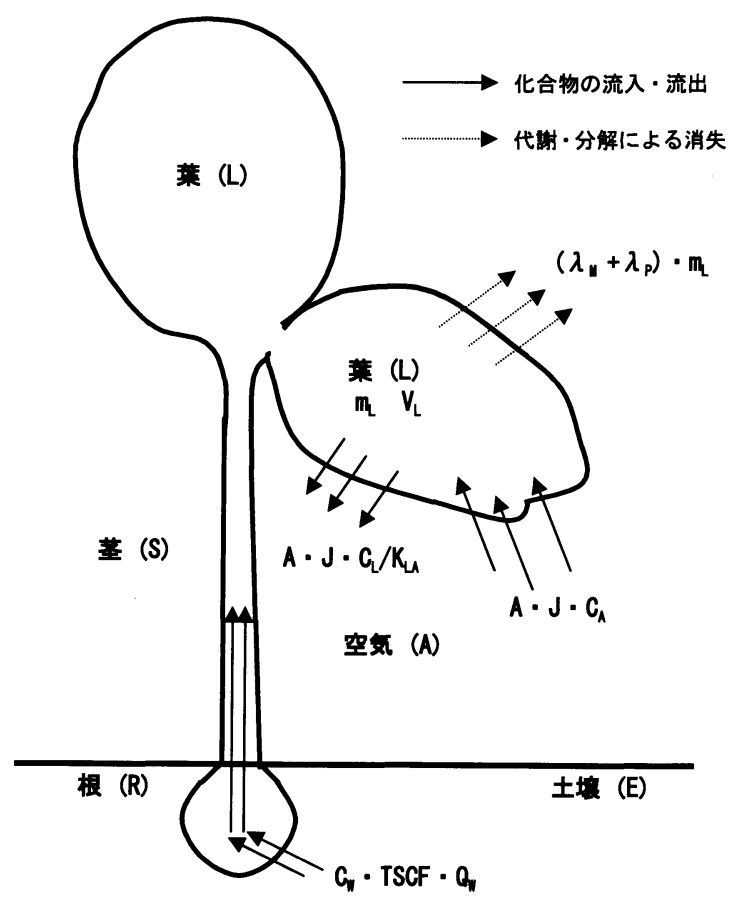

図 4 Trapp らの Plant X モデル概要

$\mathrm{V}$ は各区画の体積, $\mathrm{m}$ は重さ. 各式の表す意味については下 記のとおり。

$\mathrm{C}_{\mathrm{W}} \cdot \mathrm{TSCF} \cdot \mathrm{Q}_{\mathrm{w}}\left(\right.$ 根からの取り込み), $\mathrm{A} \cdot \mathrm{J} \cdot \mathrm{C}_{\mathrm{A}}($ 空気か ら葉への取り込み), $\mathrm{A} \cdot \mathrm{J} \cdot \mathrm{C}_{\mathrm{L}} / \mathrm{K}_{\mathrm{LA}}$ (葉から空気への放出), $\left(\lambda_{\mathrm{M}}+\lambda_{\mathrm{p}}\right) \cdot \mathrm{m}_{\mathrm{L}}$ (代謝・分解による消失).
(1) より $\mathrm{K}_{\mathrm{LA}}$ を求めることとなる.

なお, PlantX は農薬の分解消失要素として代謝による分 解速度定数 $\lambda_{\mathrm{M}}$, 光分解による分解速度定数 $\lambda_{\mathrm{p}}$ の必要性に つき唱えているが，具体的な求め方については述べられて いない。

以上に挙げた式をまとめると植物の地上部に取り込まれ る農薬量 $(\mathrm{g} / \mathrm{sec})$ について算出する式は下記のように示さ れる(図 4).

$$
\begin{aligned}
\mathrm{dm}_{\mathrm{L}} / \mathrm{dt}= & \mathrm{C}_{\mathrm{W}} \cdot \mathrm{TSCF} \cdot \mathrm{Q}_{\mathrm{w}} \quad(\text { 根からの取り込み }) \\
& +\mathrm{A} \cdot \mathrm{J} \cdot\left(\mathrm{C}_{\mathrm{A}}-\mathrm{C}_{\mathrm{L}} / \mathrm{K}_{\mathrm{LA}}\right)(\text { 空気中からの取り込み }) \\
& -\left(\lambda_{\mathrm{M}}+\lambda_{\mathrm{p}}\right) \cdot \mathrm{m}_{\mathrm{L}} \quad(\text { 代謝 } \cdot \text { 分解による消失 })
\end{aligned}
$$

ここで $\mathrm{m}_{\mathrm{L}}$ は葉の重さ $(\mathrm{g})$ である.

これを取り込み濃度で表すと, $\mathrm{C}_{\mathrm{L}}=\mathrm{m}_{\mathrm{L}} / \mathrm{V}_{\mathrm{L}}$ として，

$$
\begin{aligned}
\mathrm{dC} C_{\mathrm{L}} / \mathrm{dt}= & \mathrm{C}_{\mathrm{W}} \cdot \mathrm{TSCF} \cdot\left(\mathrm{Q}_{\mathrm{w}} / \mathrm{V}_{\mathrm{L}}\right)+\mathrm{A} \cdot \mathrm{J} \cdot\left[\left(\mathrm{C}_{\mathrm{A}} / \mathrm{V}_{\mathrm{L}}\right)\right. \\
& \left.-\mathrm{C}_{\mathrm{L}} /\left(\mathrm{K}_{\mathrm{LA}} \cdot \mathrm{V}_{\mathrm{L}}\right)\right]-\left(\lambda_{\mathrm{E}}+\lambda_{\mathrm{G}}\right) \cdot \mathrm{C}_{\mathrm{L}}
\end{aligned}
$$

$\mathrm{V}_{\mathrm{L}}$ は葉の体積 $\left(\mathrm{m}^{3}\right), \lambda_{\mathrm{G}}$ は成長速度定数 $(1 / \mathrm{sec})$ で $\lambda_{\mathrm{G}}=\ln$ $\left(\mathrm{V}_{\text {end }} / \mathrm{V}_{0}\right) / \mathrm{t}$ と表される。 $\mathrm{V}_{\text {end }}$ と $\mathrm{V}_{0}$ はそれぞれ成長終了時 $(\mathrm{t})$, 成長開始時の植物の体積である.

この簡易型 PlantX モデルが現在唯一植物への化学物質 の取り込みモデルとして EUの登録に正式に用いられてい るものである. 改良型の新 PlantX モデル ${ }^{5,20)}$ では植物を 根, 葉, 茎, 実と 4 つの区画に分け, 区画（コンパートメ ント）毎に農薬の残留量が求められるように各々計算式が 構築されている.

Trapp らは化合物として bromacil，植物としてダイズを 使用し, 改良型 PlantX モデルでの予測值の妥当性(Validation）を詳細に調べている ${ }^{21)}$. 処理時間を $\mathrm{x}$ 軸，植物中での bromacil の濃度を y 軸とし, PlantXより計算した根, 葉, 茎，実における各々の取り込み濃度の予測值をグラフ上に 実線で描き，経時的に測定した実測值をグラフ中に併記す ることで，視覚的に予測值と実測值のずれがわかるように 表記している. 予測值の妥当性を示寸指標となる予測值と 実測値の比 (=予測值/実測值) は約 $0.5 \sim 2.0$ であり, モデ ルとして充分使用可能と考えられる.

\section{2-2. Fugacity モデルの概要}

\section{2-2-1. Fugacity モデルの基本概念 ${ }^{22)}$}

環境中での化合物の物質収支を考之る場合，良く用いら れる概念として fugacity がある. Fugacity は化学物質が区 画（コンパートメント）から出て行こうとする圧力であり 逃散能とも言われ，単位はパスカル（Pa）である。1979 年 Mackay $^{23)}$ は低濃度であれば fugacity は区画中の化合物濃 度に比例することを見出し, $\mathrm{C}=\mathrm{f} \cdot \mathrm{Z}$ という式を立てた。こ

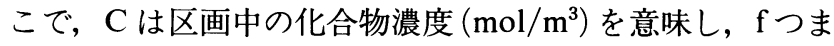
$\eta$ fugacity $(\mathrm{Pa})$ と比例している，Zはとの区画が化合物を 保有することのできる能力（化合物保有能： $\mathrm{mol} / \mathrm{m}^{3} \cdot \mathrm{Pa}$ ) を意味し，区画特有の值である．Fugacity モデルは濃度の 異なる各区画特有の性質を考慮でき，かつ区画間の物質移 
動をある程度容易に予測することが可能といわれている. 例えば隣接する 2 つ異なる区画が平衡状態にあるとき, fugacityも平衡状態となり，分配については $\mathrm{Z}$ 值で表すこ とができる. 化合物保有能 $\mathrm{Z}$ 值は化合物の物理化学的性 質, 温度, 区画(空気，水，植物等)等に依存する。 $\mathrm{Z}$ 值が 大きければ大きいほど，その区画の物質保有能は高い.

Fugacity で実際に Z 值を算出する際，まず空気，水での Z 值を求めてから，他の区画の固有值を 2 相間での分配係数 を用いて求めていく方法がとられる.

\section{2-2-2. Riederer のモデル}

Riederer は空気中から植物への農薬の取り込みについて 空気 $(\mathrm{A})$, 水 $(\mathrm{W})$, 植物内脂質 $(\mathrm{G})$, 表面脂質もしくは クチクラ $(\mathrm{C})$ と 4 つの区画に分けて考えた.

クチクラと空気の間での分配係数 $\mathrm{K}_{\mathrm{CA}}$ は実験にて求め るのが困難なため, ヘンリ一定数 $\mathrm{K}_{\mathrm{AW}}$ ，クチクラと水の間 の分配係数 $\mathrm{K}_{\mathrm{CW}}$ を用いて間接的に求めている.

$$
\mathrm{K}_{\mathrm{CA}}=\mathrm{K}_{\mathrm{CW}} / \mathrm{K}_{\mathrm{AW}}
$$

Riederer は $\mathrm{K}_{\mathrm{Aw}}, \mathrm{K}_{\mathrm{CW}}$, 植物内脂質と水の間の分配係数 $\mathrm{K}_{\mathrm{GW}}\left(\mathrm{K}_{\mathrm{ow}}\right.$ にて代用) を使用し fugacity モデルをもとにクチ クラ $(\mathrm{C})$, ならびに植物内脂質 $(\mathrm{G})$ に取り込まれる農薬 の濃度を計算する式を構築した. ちなみに主要な区画の化 合物保有能 Z 值は以下のように定義される。

$$
\mathrm{Z}_{\mathrm{A}}=1 /(\mathrm{R} \cdot \mathrm{T}), \mathrm{Z}_{\mathrm{W}}=1 / \mathrm{H}, \mathrm{Z}_{\mathrm{C}}=\mathrm{Z}_{\mathrm{W}} \cdot \mathrm{K}_{\mathrm{CW}}, \mathrm{Z}_{\mathrm{G}}=\mathrm{Z}_{\mathrm{W}} \cdot \mathrm{K}_{\mathrm{GW}}
$$

植物内脂質とクチクラが植物内で均一に存在すると仮定し た場合, 平衡状態における葉全体の $\mathrm{Z}$ 値は, $\mathrm{Z}_{\mathrm{L}}=\sum_{\mathrm{i}=1}^{\mathrm{n}} \mathrm{V}_{\mathrm{i}} \cdot \mathrm{Z}_{\mathrm{i}}$ と なる。なお， $V_{1}$ はそれぞれの区画の相対的体積を示す。

Riederer は fugacity を考えるとき，植物表面と空気の間 で分配平衡到達に要する時間の重要性についても議論して いる，特に植物と空気間での化合物の分配については植物 表面上に存在する化合物保有能の非常に高いクチクラ層の 影響を大きく受けるため, 単純に fugacity を応用すると子 測値が過大評価となる可能性について触れている.しかし， Riederer の提案する分配平衡時間を考慮した式自体，化合 物の移行・代謝による減少，もしくは植物の生長による見 かけ上の濃度減少が含まれておらず，あまり正確な議論は できない.

なお，Riedererの取り込みモデルについては予測值の妥 当性の評価は実施されておらず，理論優先のモデルとなっ ている. そのため, 今後予測値の妥当性の評価も含めて大 きな課題を残している。

\section{2-2-3. Mackay らのモデル4,8)}

Mackay らは化合物の移行・消失による物質収支につい て D 值 $(\mathrm{mol} / \mathrm{Pa} \cdot \mathrm{hr})$, もしくは反応速度である $\mathrm{D} \cdot \mathrm{f}$ 值 $(\mathrm{mol} / \mathrm{hr})$ を使い, 取り込みモデルを構築した。このモデル では散布等による化合物の初期流入量を $\mathrm{E}(\mathrm{mol} / \mathrm{hr})$ と設 定し, 化合物は最も大きい D 值の経路を通って移行並びに 分解することとなる.
主要な $\mathrm{D}$ 值を $\mathrm{Z}$ 值から求める方法は以下のとおりであ る.

1. 区画間での拡散による移動は $\mathrm{D}=\mathrm{k} \cdot \mathrm{A} \cdot \mathrm{Z} \quad(\mathrm{mol} / \mathrm{Pa} \cdot$ hr) で表される。ここで，k は移行係数 (mass transfer coefficient : m/hr), A は 2 つ異なる区画の接触面 積 $\left(\mathrm{m}^{2}\right)$ を表す.

2. 水や空気のような一定の体積を持つ物質の流れ (bulk flow) に沿う拡散能は $\mathrm{D}=\mathrm{G} \cdot \mathrm{Z}(\mathrm{mol} / \mathrm{Pa} \cdot \mathrm{hr})$ で表される。ここで，G は区画内の位相の流速 $\left(\mathrm{m}^{3} /\right.$ hr）である.

3. 反応による (代謝を含む) 化合物の消失は $\mathrm{D}=\mathrm{k}_{\mathrm{R}} \cdot \mathrm{V} \cdot$ $\mathrm{Z}(\mathrm{mol} / \mathrm{Pa} \cdot \mathrm{hr})$ で表される。ここで $\mathrm{k}_{\mathrm{R}}$ は一次反応速 度定数 $(1 / \mathrm{hr}), \mathrm{V}$ は区画の体積 $\left(\mathrm{m}^{3}\right)$ である。

次に上記の手法にて得られた個々の D 值を組み合わせて, 各区画中での化合物の移行・代謝による物質収支を総合的 に表す D 值を求める. 具体的には, 独立し連続して進行す る移行・分解については D 值の単純な和, 平行して同時に 進行する移行・分解については D 值の逆数の和と定義し た.

以上の概念をもとに，それぞれの区画における流入なら びに消失によるマスバランスは以下のよjな式で示すこと ができる（図 5).

$$
\mathrm{d}(\mathrm{V} \cdot \mathrm{Z} \cdot \mathrm{f}) / \mathrm{dt}=\mathrm{d}(\mathrm{V} \cdot \mathrm{C}) / \mathrm{dt}=\mathrm{E}+\sum\left(\mathrm{D}_{\mathrm{i}} \cdot \mathrm{f}_{\mathrm{i}}\right)-\mathrm{f} \cdot \sum \mathrm{D}_{\mathrm{O}}
$$

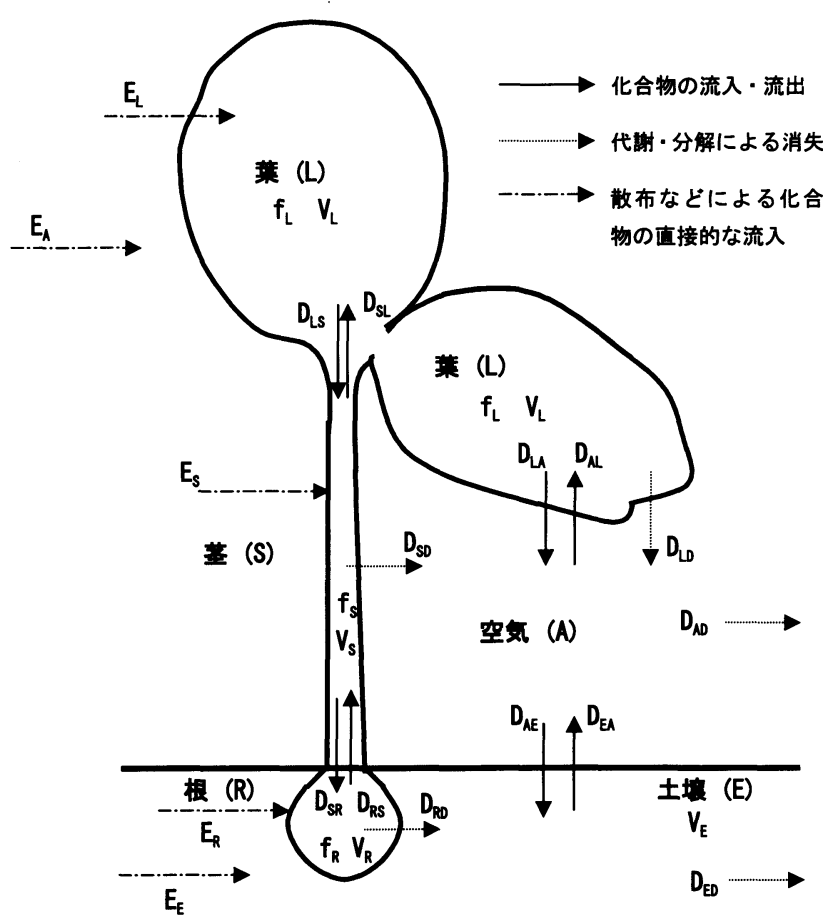

図 5 Mackay らの fugacity モデル概要

$\mathrm{V}$ は各区画の体積, $\mathrm{m}$ は重さ, $\mathrm{E}$ は目的の区画への散布等に よる直接的な化合物の流入量 (mol/hr), D は fugacity $\mathrm{f}$ 值 を持つ各々の区画からの流入，流出ならびに分解による損 失を示す值 $(\mathrm{mol} / \mathrm{Pa} \cdot \mathrm{hr})$ である。 
表 1 Mackay らの fugacity モデル：各分画の計算式

\begin{tabular}{|c|c|c|c|c|c|c|c|c|c|c|c|c|c|}
\hline & & \multicolumn{6}{|c|}{ 流入量 } & \multicolumn{6}{|c|}{ 流出量 } \\
\hline & & & Air & Earth & Root & Stem & Leaf & Air & Earth & Root & Stem & Leaf & 代謝消失 \\
\hline 空気 (Air) & $\mathrm{V}_{\mathrm{A}} Z_{\mathrm{A}} \mathrm{df}_{\mathrm{A}} / \mathrm{dt}=$ & $\mathrm{E}_{\mathrm{A}}$ & & $+\mathrm{fE}_{\mathrm{E}} \mathrm{DEA}_{\mathrm{A}}$ & & & $+\mathrm{f}_{\mathrm{L}} \mathrm{D}_{\mathrm{LA}}$ & & $-f_{A} D_{A E}$ & & & $\cdot \mathrm{f}_{\mathrm{A}} \mathrm{D}_{\mathrm{AL}}$ & $-f_{A} D_{A D}$ \\
\hline 土 (Earth) & $\mathrm{V}_{\mathrm{E}} Z_{\mathrm{E}} \mathrm{dfE} / \mathrm{dt}=$ & $\mathrm{E}_{\mathrm{E}}$ & $+\mathrm{f}_{\mathrm{A}} \mathrm{D}_{\mathrm{AE}}$ & & $+\mathrm{f}_{\mathrm{R}} \mathrm{D}_{\mathrm{RE}}$ & & & $-f_{E} D_{E A}$ & & $-f_{E} D_{E R}$ & & & $f_{E E} D_{E D}$ \\
\hline 根（Root） & $\mathrm{V}_{\mathrm{R}} \mathrm{Z}_{\mathrm{R}} \mathrm{df} / \mathrm{dt}=$ & $E_{R}$ & & $+\mathrm{fE}_{\mathrm{E}} \mathrm{DER}_{\mathrm{R}}$ & & $+\mathrm{fSD}_{\mathrm{SR}}$ & & & $f_{R} D_{R E}$ & & $\cdot f_{R} D_{R S}$ & & $f_{\mathrm{R}} \mathrm{D}_{\mathrm{RD}}$ \\
\hline 茎（Stem） & $V_{s} Z_{s} d_{f s} / d t=$ & Es & & & $+\mathrm{fR}_{\mathrm{R}} \mathrm{D}_{\mathrm{RS}}$ & & $+\mathrm{fL}_{\mathrm{L}} \mathrm{D}_{\mathrm{LS}}$ & & & -fSDS & & - $\mathrm{fSDSL}_{\mathrm{SL}}$ & $-\mathrm{fsDSD}_{\mathrm{s}}$ \\
\hline 葉（Leaf） & $V_{L} Z_{L} d f_{J} / d t=$ & $\mathrm{E}_{\mathrm{L}}$ & $+\mathrm{f}_{\mathrm{A}} \mathrm{D}_{\mathrm{AL}}$ & & & $+\mathrm{fSD}_{\mathrm{SL}}$ & & $\mathrm{fL}_{\mathrm{L}} \mathrm{LA}_{\mathrm{LA}}$ & & & $-f_{L} D_{L S}$ & & $\cdot f_{L} D_{L D}$ \\
\hline
\end{tabular}

$\mathrm{V}, \mathrm{Z}$ は各区画の体積 $\left(\mathrm{m}^{3}\right)$ および $\mathrm{Z}$ 值 $\left(\mathrm{mol} / \mathrm{m}^{3} \cdot \mathrm{Pa},\right), \mathrm{E}$ は目的の区画への散布等による直接的な化合物の流入量 $(\mathrm{mol} / \mathrm{hr})$, $\mathrm{D}$ は fugacity f 值を持つ各々の区画からの流入，流出ならびに分解による損失を示す值 $(\mathrm{mol} / \mathrm{Pa} \cdot \mathrm{hr})$ である.

ここで V は各区画の体積， $\mathrm{E}$ は目的の区画への散布等によ る直接的な化合物の流入量 $(\mathrm{mol} / \mathrm{hr}), \mathrm{D}_{\mathrm{i}}$ は fugacity $\mathrm{f}_{\mathrm{i}}$ 值を 持つ他の区画からの流入を示す $\mathrm{D}$ 值， $\mathrm{D}_{\mathrm{o}}$ は目的の区画か ら流出ならびに分解による損失を示す D 值である.

この基本式をもとに植物 (葉, 茥, 根), 空気, 土㙵と 5 つ区画に分けて，それぞれの区画について化合物の流入な らびに流出を示す式を構築している（表 1).

Mackayらの取り込みモデルについてはTrappらと同 様, 予測值の妥当性の評価は bromacil を使用しダイズにて 行っている ${ }^{24)}$. 測定点は取り込み後 72 時間後の一点のみで あるが，予測值の妥当性を示す予測值と実測值の比は葉で 1.53 ，茎で $1.64 ，$ 根で 0.88 と良好な結果を得ている.

\section{3. 植物への取り込みモデルの限界}

以上のように植物への取り込みモデルについて述べてき たが，これらモデルには明らかに限界がある。よって，そ の限界を詳細に理解した上でモデルを使用するということ は必須条件となる。

\section{PlantX モデルの限界点}

○モデルには実に該当する区画の計算式がなく，そのため 実を生成する植物には適用不可である。

・同様に根菜類根部には適用できない.

-モデルにおいて植物は幾何級数的に生長するものと仮定 しているため，成熟した植物には適用できない。

- 非解離性物質のみ扱える.

- TSCFについては特に高脂溶性物質において適用でき ない場合が多い.

\section{Fugacity モデルの限界点}

Fugacity モデルは $2 つ の$ 異なる区画間での平衡状態が 基本となっており，その平衡状態は一瞬にて到達するとい う大きな前提が必要となる。しかしながら，自然界での物 質交換反応が短期間に平衡状態に到達したか否かの判断を 下すのは困難である，例之ば，揮発性が高く，高脂用性の 化合物について植物表面上のクチクラ層と空気の間での平
衡を考之た場合，事実上平衡状態に到達する為にはかなり の時間を要する，そのため，モデルにて予測される植物中 への取り込み量は実際の取り込み量と比べて過大評価とな る場合がある.また, fugacity モデルでは区画を構成する物 質及びその配置が均一であり，かつ隣接する 2 つの区画間 での物質のやり取りが均一に行われているという仮定が必 要である。しかしながら，植物のようにそれぞれの細胞が 独立した働きを持ち，かつ様々な細胞と相互的に関わり合 う形態を持つ対象においては，大幅な簡素化・理想化が必 要となってくる.

\section{4. 光の他の最新の植物への取り込みモデル}

\section{4-1. Satchivi らのモデル9)}

米イリノイ大学の Satchivi の取り込みモデルは主として 茎葉処理した農薬の植物への取り込み，移行について予測 值を計算することを目的としており，呼称は ERMESSEで ある。このモデルは化合物側のパラメータとして $\log \mathrm{K}_{\text {ow }}$ だけでなくモル体積， $\mathrm{p} K \mathrm{a}$ を利用し，植物側のパラメータ として導管・篩管のつながり, 細胞膜透過率, アポプラス ト・シンプラスト・蒸散流中の $\mathrm{pH}$ 等を考慮したものとなっ ている．モデルの概念として葉面に付着した農薬を以下に 示す $5 つ$ 主要過程に分けて植物への取り込み・移行を論 じている．具体的には(1)葉面に付着した農薬のクチクラ通 過，(2)葉肉細胞シンプラストへの取り込み，(3)篩管への取 ク込み，(4)篩管を通じた長距離輸送，(5)穊管からの溶脱で ある．この基本概念に加えて代謝分解による消失，篩管と 導管の間での物質交換等を盛り込み，非常に複雑なモデル 構成となっている. このように ERMESSE は数多くの数式 を活用しているため，個々の数式に対していかに正確なパ ラメータを揃えることができるかが予測值の信憑性に大き く関わってくるものと考之られる。しかし，現時点におい てデータ不足の感は否めなく，また基礎データの収集はか なり困難な作業と思われるため，実質的な活用性について は時間を要するものと考えられる。 
葉面に付着した農薬の植物内部への浸透率に関する ERMESSE の予測值の妥当性を検討したところ, 妥当性を示 す指標となる予測值と実測值（文献值，17 化合物）の比は 0.7〜3.7であった ${ }^{25)}$. しかしながら, ERMESSEの主目的で ある葉の表面に付着した農薬の他の植物部位への篩管を通 じた移行に関する予測值の妥当性評価は行われていない。

\section{4-2. Chiou らのモデル ${ }^{10)}$}

Chiou らの取り込みモデルは植物への農薬の取り込み量 を植物中の有機物質への化合物の分配，ならびに植物中に 取り込まれる水に溶解する化合物の量から総合的に計算す るモデルである。このモデルも分配の概念を応用している ため, 基本となるのは植物の根の外溶液中での農薬濃度で ある. 特に Chiou らは水耕液ではなく土䁃から植物への取 ク込みについても考慮するため, 根の周りの土堙間吵に存 在する水の農薬濃度に注目し，その濃度については農薬の 水と土壤有機物質への分配により求めている。しかし，こ のモデルでは植物中に取り込まれた化合物は植物中に均一 に分散されていること,農薬の土㙵/水への分配は単純に土 壤の有機物含量に支配されていること等を前提としてお $\eta$ ，かつ代謝の要因が全く考慮されていないことから得ら れた予測值の精度については今後議論を要するものと考之 られる.

なお，予測值の妥当性評価については実測值測定条件と 予測值算出条件（土性等のパラメー夕）に大きな違いがあ るため，正確な議論はできないが，例えばニンジンおよび ハツカダイコン中の dieldrinの予測值と実測值との比は 各々 $0.04 〜 0.2,0.08 \sim 0.38$ という結果であった.

\section{4-3. 著者らのモデル ${ }^{111}$}

著者らの取り込みモデルでは農薬の植物中での残留量を 表す際, 取り込みによる農薬の増加量だけでなく, 代謝・ 分解による損失量にも重点をおいた。化合物の分解速度定 数は実験より得られた代謝デー夕をもとに一次反応式より 求める方法を採用し, 特に代謝・分解を受けやすい農薬の 植物中での残留量の予測が可能となった．また，農薬は蒸 散流にのって導管中を移動する際，導管の構成成分である リグニンに吸着されるため, 導管下部と上部での蒸散流中 の農薬濃度が異なる ${ }^{26)}$. この事実は特に実に流入する導管 経由での農薬量に大きな影響を与えるため，新たに UTSCF（upstream TSCF）という導管上部での農薬の分配 係数を実への取り込みモデルに導入した，現時点において は農薬の分解速度定数, UTSCF とも実験により求める必 要があるため予測值を計算する上での制約も多い。しかし 今後これらのパラメータのデータベース化が進めば，より 利用価値のある取り込みモデルとなる可能性があるものと 考之る.

なお，農薬 6 剂 (furametpyr, diethofencarb, procymidone, diclocymet, diniconazole-M, pyriproxyfen) でダイズおよび
ホウレンソウを使用し，茎葉部モデルの予測值の妥当性を 評価したところ，その指標値となる予測値と実測值の比は 0.44 １.49であった。

\section{5.おわりに}

農薬は植物防護という観点から非常に重要な化合物であ る.これら農薬は植物または土㙵に直接散布されるため, 農薬の登録取得にあたり，植物にどの程度残留するかを見 極めることは農薬の開発会社ならびに一般消費者にとって も重大な関心事である．現在，固場における残留試験のみ において植物中での残留量は求められているが，欧州，日 本，米国において新規登録ならびに再登録に申請される莫 大な数に上る農薬の安全性評価を効率よく，的確かつ短期 間に進めるためには，今後中長期にわたりより精度の高い 植物への取り込み（残留）モデルの開発が望まれる。

本稿の執筆に際してご協力をいただいた住友化学工業 (株)の 瀧本善之博士，片木敏行博士に感謝いたします。

\section{引用 文 献}

1) R. F. Carsel, J. C. Imhoff, P. R. Hummel, J. M. Cheplick and A. S. Donigian Jr. : "PRZM-3, A Model for Predicting Pesticide and Nitrogen Fate in the Crop Root and Unsaturated Soil Zones: Users Manual for Release 3.0," http : // www.epa.gov/ceampubl/przm3.htm.

2) L. A. Burns: "Exposure Analysis Modeling System (EXAMS II) User's Guide for Version 2.97.5," United States Environmental Protection Agency, EPA600/R-97/ 047, March 1997.

3) M. Riederer : Environ. Sci. Technol. 24, 829-837 (1990).

4) S. Paterson, D. Mackay and C. Mc Farlane : Environ. Sci. Technol. 28, 2259-2266 (1994).

5) S. Trapp and M. Matthies : Environ. Sci. Technol. 29, 23332338 (1995).

6) S. Trapp : "Plant Contamination," ed. by S. Trapp and J. C. Mc Farlane, CRC Press, Inc., Boca Raton, FL, pp. 107$151,1995$.

7) M. Riederer : "Plant Contamination," ed. by S. Trapp and J. C. Mc Farlane, CRC Press, Inc., Boca Raton, FL, pp. 153-190, 1995.

8) S. Paterson and D. Mackay: "Plant Contamination," ed. by S. Trapp and J. C. Mc Farlane, CRC Press, Inc., Boca Raton, FL, pp. 191-214, 1995.

9) N. M. Satchivi, E. W. Stoller, L. M. Wax and D. P. Briskin : Pestic. Biochem. Physiol. 68, 67-84 (2000).

10) C. T. Chiou, G. Sheng and M. Manes: Environ. Sci. Technol. 35, 1437-1444 (2001).

11) T. Fujisawa, K. Ichise, M. Fukushima, T. Katagi and Y. Takimoto: J. Agric. Food Chem. 50, 532-537 (2002).

12) EUSES, European Union System for the Evaluation of Substances. National Institute of Public Health and the Environment (RIVM), Netherlands (1996).

13) T. G. Vermeire, D. T. Jager, B. Bussian, J. Devillers, K. den Haan, B. Hansen, I. Lundberg, H. Niessen, S. Robertson, H. Tyle and P. T. J. van der Zandt : Chemosphere 34, 18231836 (1997). 
14) S. Trapp and S. Schwarts: Chemosphere 41, 965-971 (2000).

15) G. G. Briggs, R. H. Bromilow and A. A. Evans : Pestic. Sci. 13, 495-504 (1982).

16) G. G. Briggs, R. H. Bromilow, A. A. Evans and M. Williams : Pestic. Sci. 14, 492-500 (1983).

17) F. C. Hsu, R. L. Marxmiller and A. Y. S. Yang: Plant Physiol. 93, 1573-1578 (1990).

18) S. Trapp : Pest Manag. Sci. 56, 767-778 (2000).

19) S. Trapp and L. Pussemier: Chemosphere 22, 327-339 (1991).

20) GSF - Forschungszentrum für Umwelt und Gesundheit, UFIS model home page: "PlantX - chemical uptake in plants," http : //www.gsf.de/UFIS/ufis/modell15/modell. html.

21) S. Trapp, C. Mc Farlane and M. Matthies: Environ. Tox. Chem. 13, 413-422 (1994).

22) D. Mackay: "Multimedia Environmental Models, the Fugacity Approach," ed. by D. Mackay, CRC Press, LLC., Boca Raton, FL, 2001.

23) D. Mackay : Environ. Sci. Technol. 13, 1218-1223 (1979).

24) H. Hung and D. Mackay: Chemosphere 35, 959-977 (1997).

25) N. M. Satchivi, E. W. Stoller, L. M. Wax and D. P. Briskin : Pestic. Biochem. Physiol. 68, 85-95 (2000).

26) M. Uchida : Pestic. Biochem. Physiol. 14, 249-255 (1980). 